\title{
Motivation of Employees in the Public Institutions
}

\author{
Evelyne Ingrid Mitu \\ evelynetudorache@yahoo.com \\ Loredana Comanescu \\ loryela@yahoo.com \\ Valahia University of Targoviste, Romania
}

\begin{abstract}
When it comes to explaining the behavior of a certain person within an organizational group, we often fail to figure out the intimate lifestyles that animate him, the hidden part of his personality that forces him to do so and not otherwise. We are too preoccupied with measuring I.Q., define it in character, neglecting that inner force that guides and keeps his energetically action. This is the motivation, essential for human activity, for understanding and explaining behavior.
\end{abstract}

Keywords: motivation, people, attitude, needs, satisfactions.

\section{Introduction}

The key issue of motivation is to determine the means by which members of the organization, each with its own needs and with its own personality, can be stimulated to contribute positively and efficiently to the achievement of the established goals.

Defined as the totality of internal moves of conduct, whether inborn or acquired, conscious or unconscious, simple physiological needs or abstract ideals, motivation is understood either as a set of motifs or as a process of motivation or push to action.

In other words, the factors that trigger, energize and motivate man in activity are defined as motivational. The motivation is influenced by three categories of such factors:

- Requirements - through their energizing, impulse, impetuous side;

- Trends - emotional relationships and attitudes towards different aspects of the environment and towards one's own person;

- Immediate or imaginary objects and circumstances that are acquired by purpose.

- Summarizing, the underlying concepts of motivation as a process are as follows:

- Reasons (the wishes and impulses that lead people to act in order to achieve goals);

- Primary needs and psychosocial needs;

- Expectations.

Thus, the particular complexity of the concept is observed, being a multidimensional one, essential for human activity and its understanding and explanation. Exposing some aspects will be enlightening.

First of all, such complexity also arises from the fact that motivational phenomena can not be directly observed, which makes their identification and name difficult

Therefore, the issue of motivation is essential to human activity, to understanding and explaining man's organizational behavior. A good knowledge of the motivational phenomena of members of an organization can prove useful for the following directions:

- explaining and understanding the different organizational behaviors of people;

- to prevent or improve behaviors due to the entry into operation of different types of motivation;

- stimulating the growth of motivation and avoiding its loss, thus contributing to maximizing the efficiency of organizations. 


\section{Types of motivation}

In the classification of different types of motivation, the difficulty of choosing the criterion that could be used from the very beginning. Starting from the main categories of stimuli involved in professional life, we identify the following key stimuli:

- Money, financial, economic incentives - economic motivation;

- Work, professional activity - professional motivation;

- Interaction between the members of the working group - psychosocial motivation.

Table 1. - Types of motivation for organizational behavior

\begin{tabular}{|c|c|c|}
\hline Categories of stimuli & Certain types of stimuli & Types of motivation \\
\hline Material & $\begin{array}{c}\text { The wage } \\
\text { Participation in benefits } \\
\text { Awards }\end{array}$ & Economic \\
\hline Work and her conditions & $\begin{array}{c}\text { Work itself } \\
\text { Physical conditions of work } \\
\text { The finality of work }\end{array}$ & Professional \\
\hline $\begin{array}{c}\text { Interaction of members of } \\
\text { working groups }\end{array}$ & $\begin{array}{c}\text { Purpose of the group } \\
\text { Group Structure } \\
\text { Group size }\end{array}$ & Psychosial \\
\hline
\end{tabular}

Economic motivation is driven by financial, financial stimuli. Money has no incentive value, but they can get motivational valences by being the main means by which man satisfies most of his needs. It is more useful to use the most varied forms of remuneration so as to meet as many needs as possible. In addition, it has been found that one and the same form of payment may have positive and negative effects under certain conditions; so proper handling of the pay system is required.

Research on financial incentives has shown that salary occupies 3-4, or even 6-7, on lists containing other incentives able to motivate people's behavior. As far as remuneration supplements are concerned, they have more preventative than creative influence, they prevent the emergence of negative attitudes, but they do not create positive attitudes.

Professional motivation has as a stimulating source the work situation. It comes from man's reporting to his work, his peculiarities. As complex human activity, work can be regarded as an expense of either physical or intellectual energy does not lead as usual to an exhaustion of the body; within certain limits, this energy consumption can be pleasant in itself, becoming a true motivational source;

Working conditions are another parameter that can become a motivational stimulus.

The problem which arises that the same working conditions may motivate different individuals differently or even one and the same individual at different times.

Psychosocial motivation derives from the fact that in the work process man relates not only to his work but also to his fellow workers, to other colleagues or work partners, to his / her group or to other neighboring groups. The goal of the group is to stimulate and engage all members of the group in activity, thus offering the opportunity to achieve increased performance by uniting the efforts. The psychosocial factor most often cited as a source for triggering the psychosocial motivation of labor is the interaction of the members as well as the nature and intensity of the relationships that are established between them. But not every kind of interaction triggers motivation. The stimulus value has only that interaction that respects certain rules: the nature, quality and intensity of the interaction among the members of the group, the value of the relationships for those entering the interaction; sense of relationship manifestation; the similarity of partners interacting; type of interpersonal relationships; the extent to which it allows the achievement of individual goals. 
The size of the group stimulates the motivation of the participants in an organization not by itself, but by its own characteristics or by the psychosocial phenomena it occasioned. Among these needs satisfied by psychosocial stimuli we can include: the need for grouping or belonging to a group, the need for security, the need for a social status of esteem and appreciation.

\section{Methodology for the realization of the Diagnostic Analysis for Observing the Motivation of the Personnel}

The Diagnostic Analysis of Human Resources within an organization has become increasingly important in recent years, with the human resources department becoming a strategic partner in achieving the goals of an organization. This change was caused by the changes that took place in the social environment, the main role of human resources being to help the organization achieve its goals.

The objective of the research can be:

Identifying opportunities to improve the implementation of human resources performance management in the organization

\section{Tools used in research:}

A. "Questionnaire on the need to identify possibilities for improving the implementation of human resources performance management in the organization".

This questionnaire identifies whether the person prefers to be led according to the "X" or "Y" theory.

Thus, a manager of the "X" theory will be inclined to believe and believe that:

- In general, his subordinates do not want to work. If he had a choice, he would not want to work for the employer, avoiding it whenever possible.

- For this reason, the tasks must be well structured and specified. Even if appropriate rewards are given, many employees avoid making the effort that the organization needs.

- Most people prefer to be led. They do not want to bear the burden of responsibility and avoid

it. They have low ambitions and prefer a safe, steady life.

- A manager of the "Y" theory will tend to believe that:

- Work is a play that offers satisfaction and meaning to life.

- If people are sentimental about being involved, then they will self-direction and self-control to achieve the company's goals.

- Imagination, ingenuity and creativity in problem solving is widely shared among employees.

- In modern organizations, the intellectual potential of employees is only partially used. People are able to cope with much more complex issues.

Questionnaire Theory X - Y

By carefully reading each sentence, the corresponding score is given using the scale:

$0=$ Never, $1=$ Seldom, $2=$ Occasionally, $3=$ Often, $4=$ Often, $5=$ Always

1. I prefer to be involved and consulted by my boss about how to do my best work.

2. I want to learn and acquire skills outside my area of responsibility.

3. I prefer to work without interference from the boss, but I can ask for help if I need it.

4. I work well and very productively without the pressure of the boss or the threat of losing the job.

5. When I leave the organization I want to participate in a "departure interview" to tell me the point of view.

6. I want to be rewarded and awarded because I work well and efficiently.

7. I want to increase my responsibilities.

8. I want to be prepared, to learn to do new things.

9. Prefer to have friendship with my boss and the manager.

10. I would like to be able to discuss my problems, worries or suggestions with my boss or other manager. 
11. I want to know the goals and objectives of the organization.

12. I wish to be permanently informed about the performance of the organization.

13. I would like to be given the opportunity to solve a problem related to my work.

14. I want to be informed by my boss about what's going on in the organization.

15. I want to have regular meetings with my boss to discuss how I can develop and improve my performance.

Giving the score of each answer, the interpretation of the result will be as follows:

From 60 to 75 , the $\mathrm{Y}$ theory is strongly preferred; from 45 to 59, the $\mathrm{Y}$ theory is generally preferred; from 16 to 44 , generally the theory $\mathrm{X}$ is preferred and from 0 to 15 , the theory $\mathrm{X}$ is strongly preferred.

B. "Maslow Needs Hierarchy"

The statements below should be hierarchized in order of importance, giving the 1 most important, 2 the most important, and so on the 35th.

1. A permanent and secure job.

2. Self-esteem.

3. Fixed working hours, rest periods, free time.

4. High salary.

5. A prestigious organization.

6. Proper working conditions.

7. Other facilities (ex, service machine).

8. The ability to provide quality work.

9. Career development career.

10. Good relationships with colleagues.

11. Well organized communication.

12. Possibility to take risks.

13. A good position or a high status in the organization.

14. Possibilities for promotion.

15. Interesting, stimulating work.

16. Beneficial retirement.

17. Offering certain services: sports, travel.

18. Solid, time-resistant organization.

19. Do not have to work hard.

20. Be aware of what's happening in the organization.

21. Sentimental I'm doing something important.

22. Member of the organization's representative bodies.

23. Precise, well-defined tasks.

24. A boss who appreciates the well done thing.

25 . The ability to easily create social (social) relationships.

26. Work in a dynamic organization / structure.

27. Participate in as many seminars, courses as possible.

28. Agree with the organization's objectives.

29. Freedom as regards professional activity.

30. Opportunities for personal development.

31. Penalize poor performance.

32. Have a competent boss.

33. The possibility to schedule my vacation periods alone.

34. Direct and permanent guidance.

35. Work in the neighborhood 


\begin{tabular}{|c|c|c|}
\hline Groups of needs & Number of question & Type of need / reasons \\
\hline I. & $3,6,7,17,19,33,35$ & Physiological / organic \\
\hline II. & $1,9,16,18,23,31,34$ & Safety \\
\hline III. & $10,11,20,22,24,25,32$ & Sociale \\
\hline IV. & $2,4,5,8,13,21,29$ & honor, considerațion \\
\hline V. & $12,14,15,26,27,28,30$ & Auto-update \\
\hline \multicolumn{2}{|c}{} \\
\hline
\end{tabular}

\section{Conclusions}

Taking into account the "X" and "Y" theory and the "Maslow Needs Hierarchy," we note that there are many ways to motivate employees through leadership style, job specifications, organizational events and rewards:

- Physiological needs: providing meal breaks, rest, and a sufficient reward for essential needs.

- Safety needs: Providing a safe working environment and ensuring work safety.

- Social needs: create a sense of belonging through team projects and social events.

- Need to be respected: recognizing achievements to make employees feel appreciated.

- Self-updating: Providing employees with challenges and the opportunity to reach their full potential.

But not all people are motivated by the same needs - at different times, different people can be motivated by very different factors.

It is important to understand the needs of each individual employee. In order to motivate an employee, the manager must recognize the level of the employee's needs and use these needs as motivating levers.

\section{References}

1. Chisu Ana Viorica, Handbook of Human Resources Specialist, IRECSON Publisbing House, Bucharest, 2002;

2. Gomez-Mejia R. Luis, Balkin B. David, Cardy L Robert, Managing Human Resources - Second Edition, Prentice Hall, New Jersey, 1995;

3. Johns Gary, Organizational Behavior, Economic Publishing House, Bucharest, 1998;

4. Manolescu Aurel, Managemnet of Human Resources - Third Edition, Economic Publishing House, Bucharest, 2001;

5. Mamali Cătălin, Motivational Balance and Coevolution, Scientific and Encyclopedic Publishing House, Bucharest, 1981;

6. Mathis L. Robert, Nica C. Panaite, Rusu Costache, Human Resources Management, Economic Publishing House, Bucharest, 1997;

7. Popescu-Neveanu Paul, Dictionary of Psychology, Albatros Publishing House, Bucharest, 1987;

8. Roșca Alexandru, General Psychology, Didactic and Pedagogical Publishing House, Bucharest, 1996;

9. Paraschiv Vagu, Stegăroin Ioan, Motivation in work, from theory to practice, Bibliotheca publishing house, Târgoviste, 2007;

10. Vlăsceanu Mibaela, Psychosociology of Organizations and Management, Paidea Publishing House, Bucharest, 1993;

11. Zlate Mielu, Fundamentals of Psychology - Part II, Hyperion XXI Publishing House, Bucharest, 1991; 12. Zorlentan, T and others Organization Management, Volume I and II, Holding Reporter, Bucharest, 1996. 